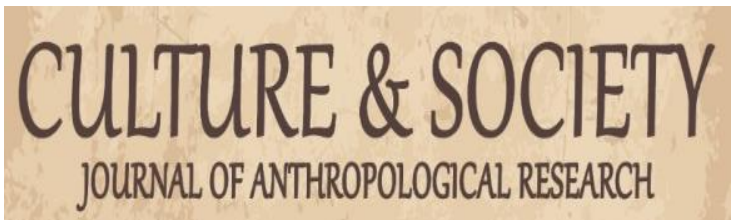

Culture \& Society: Journal of Anthropological Research

VOL. 1 NO. 1 SEPTEMBER 2019

http://culture.ppj.unp.ac.id

Email: culture@ppj.unp.ac.id

ISSN: 2686-343X (E-ISSN) 2686-3421 (P-ISSN)

DOI: https://doi.org/10.24036/culture/vol1-iss1/21

\title{
Nilai-nilai Sosial dalam Hubungan Kerja Petani Gambir dengan Toke di Kenagarian Gantiang Mudiak Utara Surantih
}

\author{
Salman Alimusa ${ }^{1}$, Ikhwan Ikhwan ${ }^{2}$ \\ ${ }^{1,2}$ Universitas Negeri Padang \\ Email: salmanalimusa07@gmail.com, ichone.in@gmail.com
}

\begin{abstract}
Abstrak
Penelitian ini bertujuan untuk mengetahui bentuk dan penyebab petani gambir mempertahankan hubungan kerja dengan toke dalam konteks peminjaman, penjualan dan pemasaran hasil produksi gambir di Kenagarian Gantiang Mudiak Utara Surantih. Teori yang dipakai dalam penelitian ini adalah teori pertukaran yang dikembangkan oleh George C. Homans. Metode yang digunakan dalam penelitian ini ialah pendekatan kualitatif dengan tipe deskriptif serta teknik pemilihan informan purposive sampling.Dalam pengumpulan data dilakukan dengan cara observasi, wawancara dengan teknik analisis data dari Miles dan Huberman. Hasil dari penelitian ini menunjukan bahwa terdapat nilai-nilai sosial budaya yang menjadi pondasi petani gambir dalam menjalin hubungan dengan toke seperti, (1) Nilai-nilai tolong menolong dalam lingkup keluarga, (2) Nilai-nilai tolong menolong dalam lingkup persahabatan, dan (3) Nilai-nilai Gotong Royong dalam lingkungan masyarakat setempat.

Kata kunci: Nilai-nilai, Hubungan Kerja, Petani dan Toke

Abstract

This study aims to determine the shape and cause of gambir farmers to mantain working relationships with the toke in teh context of borrowing, salling and marketing the results of gambir production in Kengarian Gantiang Mudiak Utara Surantih. The theory used in the study is the exchanga theory developed by George C. Homnas. The method used in this research is a qualitative approach with descriptive type and purposive sampling informant selection technique. The data collection was carried out by means observation, interviews with data analysis techniques from Miles anda Huberman. The results of this study indicate that there are socio-cultural values that are the foundation of gambier farmers in establishing relationship with toke such as, (1) Values help in the family environment, (2) Values help in friendship, and (3) Mutual cooperation values in teh local community.
\end{abstract}

Keywords: Values, Employment relations, The Farmers and the Toke

Received: August 29, 2019 Revised: September 4, 2019 Published: September 6, 2019

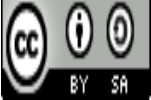




\section{Pendahuluan}

Pada hakikatnya manusia pada hakikatnya manusia tidak akan bisa hidup sendiri sebab keterbatasan akan sumberdaya yang dimiliki, maka dari itu manusia membutuhkan orang lain untuk memenuhi kebutuhan hidup seperti makan, minum dan pakaian (USMAN, ROMIS and $\mathrm{Ma}$, Farid th musa and Latare, 2015). Sehubungan dengan itu, jika dilihat dari sudut sosial manusia adalah makhluk yang tidak akan dapat hidup normal tanpa kehadiran manusia lain. Hubungan itu juga disebut dengan interaksi sosial. Suatu interkasi sosial akan terwujud apabila seseorang bergaul dengan lingkunganya. Adapun pengertian interkasi sosial menurut Soerjono Soekanto adalah hubungan yang berlangsung antara individu dengan individu, individu dengan kelompok, kelompok dengan kelompok (Soerjono, 2010).

Petani juga merupakan makhluk sosial yang membutuhkan orang lain untuk menjalankan usahanya. Salah satu aspek dalam menjalankan usaha adalah modal. Modal bagian terpenting dalam proses pengolahan usaha pertanian, danmasalah modal merupakan salah satu faktor penentu dalam meningkatkan pendapatan petani. Sebagaimana telah kita ketahui dalam teori produksi bahwa jumlah ouput nantinya akan berhubungan dengan pendapatan bergantung kepada modal kerja. Modal kerja yang tepat merupakan syarat keberhasilan suatu usaha apalagi usaha kecil menengah. Modal kerja sangat erat kaitanya dalam rangka menghitung kebutuhan modal kerja. Perhitungan modal kerja yang berbeda akan menyebabkan perhitungan kebutuhan modal kerja yang berbeda (Moehar, 2004).

Sehubungan dengan itu, petani yang berada di Kenagarian Gantiang Mudiak Utara Surantih memperoleh modal usaha dari toke dengan cara peminjaman uang untuk mengolah hasil pertaniannya dengan syarat agar hasil produksi pertanian dijual kepada toke tersebut (Mariana, 2012). Perihal peminjaman ini sering disebut sebagai sistem ijon. Sistem ijon adalah prosedur peminjaman yang dilakukan oleh petani kepada toke sebelum ia memulai mengolah hasil pertanian. Antara petani dengan toke memiliki pola hubungan yang saling berkaitan karena petani tidak memiliki modal, waktu serta transportasi yang memadai untuk menjualnya ke kota, dan toke pun tidak akan memperoleh penghasilan jika petani tidak menjual hasil produksinya kepada dia.Prosedur peminjaman dengan sistem ijon ini memang mudah dan tanpa ada prosedur yang harus dilengkapi serta tidak terikat oleh tempat dan waktu. Hal seperti ini yang menjadi daya tarik petani untuk memperoleh pinjaman dengan cepat dan efisien. Kenagarian Ganting Mudiak Utara contohnya, meskipun telah dibentuk Badan Usaha Milik Nagari (BUMNAG), serta sudah ada beberapa Bank di kecamatan Sutera (BRI, Bank Nagari, BPR, d11), ternyata petani kurang memanfaatkan keberadaanya untuk memperoleh pinjaman dengan alasan terlalu rumit dan banyak prosedural yang harus di isi dan dilengkapi. Jadi sistem ijon seperti ini bukan hanya sekedar meminjam modal tetapi cara pikir dan budaya masyarakat yang sesat.

Awalnya hubungan yang terjadi antara petani dan toke hanya sebatas hubungan ekonomi saja, namun dalam perkembangannya berubah menjadi hubungan sosial seperti ketika toke mengadakan acara atau toke ada pekerjaan yang membutuhkan tenaga orang banyak tanpa diminta petani datang membantu dan tanpa mengharapkan upah dari toke. Begitu juga sebaliknya, ketika petani membutuhkan biaya untuk menyekolahkan anaknya atau untuk berobat kedokter dan keperluan mendadak lainnya toke bersedia meminjamkan uang dengan syarat petani tersebut berlangganan dengannya. Hakikat dari adanya hubungan ini adalah proses ketergantungan yang ada dalam konteks peminjaman dan pemberian modal, penjualan dan penerimaan serta mengisi dan melengkapi (Kausar dan Komar Zaman, 2010). Antara petani dan pedagang pengumpul sama-sama menjaga hubungan ini tetap terjalin sebab ada hal yang di untungkan satu sama lain guna memenuhi kebutuhan hidup.

Keterikatan antara petani dengan toke membuat hubungan berjalan dengan harmonis dan berkesinambungan sebab ada sesuatu yang mereka anggap berharga. Petani mendapat modal usaha dari toke tanpa ada bunga yang harus dibayar, namun dilain pihak petani harus berlangganan dengan toke tersebut. Sebaliknya, toke pun tanpa ragu-ragu meminjamkan uang kepada petani untuk modal menjalankan usahanya. Berbeda dengan di daerah lain yang mana bila ada petani meminjam modal kepada toke atau sejenisnya maka akan dipatok terlebih dahulu bunga yang harus dibayar, jangka waktu peminjaman, dan konsekuensi jika telat membayar sesuai dengan peraturan yang sudah disepakati sebelumnya (Lies Sulistyowati, Ronnie S Natawidjaja, 
2013). Oleh sebab itu penelitian ini menjadi unik dan mempunyai ciri khas tersendiri dari penelitian-penelitian sebelumnya.

\section{Metode Penelitian}

Pendekatan yang peneliti gunakan untuk mengkaji permasalahan di atas adalah pendekatan kualitatif. Pendekatan kualitatif ini berusaha untukmemberikan pengertian mengenai makna suatu kejadian atau peristiwa dengan mencoba berinteraksi dengan orang-orang dalam fenomena yang akan di teliti (yusuf muri, 2016). Sehubungan dengan itu, penelitian kualitatif adalah metode penelitian yang berlandaskan pada filsafat Postpositivisme, digunakan pada kondisi meneliti obyek yang alamiah, dimana peneliti adalah instrtumen kunci, teknik pengumpulan data secara triangulasi (gabungan), analisis data bersifat induktif/kualitatif, dan hasilnya menekankan kepada makna dari pada generilisasi (sugiyono, 2007). Tipe dalam penelitian ini yang digunakan adalah studi kasus tepatnya di Kenagarian Gantiang Mudiak Utara Surantih. Studi kasus yaitu fenomena kasus yang terjadi dalam konteks yang terbatas (bounded countext). Kasus di sini dapat berupa individu, peran, kelompok kecil, organisasi, komunitas atau bahkan suatu bangsa. Jenis studi kasus yang penulis pilih adalah studi kasus intrinsik (Puwardi Kristi, 2001). Sehubungan dengan itu, sifat dari penelitian ini adalah deskriptif sebab peneliti berusah untuk menggambarkan fenomena yang berkaitan dengan nilai-nilai sosial budaya yang ada di Kenagarian Gantiang Mudiak Utara Surantih.

Pemilihan informan dilakukan dengan menggunakan teknik purposive sampling. Pemilihan teknik ini dengan landasan bahwa peneliti sudah mempertimbangkan tehadap siapa yang akan diteliti atau orang yang akan menjadi informan penelitian. Purposive sampling adalah teknik penelitian yang sudah menetapkan informan sebelum melakukan penelitian, dengan menetapkan kriteria tertentu yang harus dipenuhi oleh orang yang akan dijadikan sumber informan berdasarkan kriteria yang telah diharapkan, peneliti telah mengetahui indentitas orang-orang yang akan dijadikan informan sebelum peneltian dilakukan (Aprizal, 2016). Jumlah informan dalam penelitian ini berdasarkan Kriterianya adalah sebanyak 16 orang yang terdiri dari pemerintah Nagari selaku Wali Nagari (1 orang), toke (3 orang), dan Petani gambir selabihnya (12 orang). Teknik observasi yang peneliti lakukan dalam penelitian ini adalah mengamati secara langsung fenomena sosial yang ada di lingkungan masyarakat Gantiang Mudiak Utara Surantih. Observasi atau pengamatan lebih terfokus terhadap gejala, kejadian atau sesuatu dengan maksud menafsirakannya, mengungkapkan faktor-faktor penyebabnya, dan menumakan kaidah-kaidah yang mengaturnya(Emzir, 2014). Teknik observasi digunakan untuk melihat dan mengamati secara langsung keadaan dilapangan agar peneliti memperoleh gambaran yang lebih luas tentang permasalahan yang diteliti (Basrowi dan suwandi, 2008). Obsevasi yang dilakukan dalam penelitian ini adalah obsevasi partisipasi pasif, yaitu; peneliti datang kelokasi kegiatan orang diamati, tetapi tidak ikut terlibat dalam kegiatan tersebut(sugiyono, 2007). Peneliti datang kelokasi penelitian yaitu di Kenagarian Gantiang Mudiak Utara, namun peneliti bukan bagian dari petani gambir. Hal yang diamati oleh peneliti meliputi orang, aktivitas, latar (setting) adalah tempat, suasanadan waktu dalam melakukan penelitian tersebut di kenagarian Gantiang Mudiak Utara Kecamatan Sutera Kabupaten Pesisir Selatan.

Setelah melakukan observasi peneliti melakukan wawacara terhadap informan yang sudah ditetapkan sebelumnya yaitu Wali Nagari setempat, petani gambir dann toke. Teknik wawancara merupakan salah satu cara pengumpulan data dalam suatu penelitian. Wawancara (interview) dapat diartikan sebagai cara yang dipergunakan untuk mendapatkan informan (data) dari responden dengan cara bertanya langsung secara bertatap mungka (face to face)(Suyanto Bagong dan Sutina, 2015). Menurut Esterbrag, wawancara adalah pertemuan dua orang untuk bertukar informasi dan ide melalui tanya jawab, sehingga dapat dikonstruksikan makna dalam suatu topik (Sugiyono, 2011). Wawancara dilakukan secara terbuka dengan maksud mendapatkan data yang valid dan dilakukan berkali-kali sesuai dengan keperluan. Supaya data yang peneliti peroleh dalam penelitian akurat, valid dan sah maka dilakukan dengan teknik trigulasi data. Dalam teknik pengumpulan data, triangulasi merupakan teknik pengumpulan data yang menggabungkan berbagai teknik pengumpulan data dan sumber data yang telah ada. Dengan menggunakna teknik triangulasi data, maka sebanarnya peneliti mengumpulkan data dan sekaligus menguji kredibilitas

Culture \& Society: Journal of Anthropological Research Vol. 1, No. 1, Th. 2019 
data, yaitu dengan mengecek kredibilitas data dengan berbagai teknik pengumpulan data dan berbagai sumber (Sugiyono 2011).

\section{Hasil dan Pembahasan}

Gantiang Mudiak Utara Surantih adalah kawasan hasil pemekaran dari Nagari Surantih pada tahun 2011 yang pada mulanya terdiri dari 2 kampung yaitu, kampung Langgai dan Kampung Batu Bala. Kedua kampung ini mempunyai sejarah dan peristiwa berdirinya masingmasing namun dilain pihak kampung ini secara geografis berdekatan. Sehubungan dengan itu, kedua kampung yang dijadikan menjadi satu nagari ini kegiatan ekonomi masyarakatnya bertumpu pada sektor hasil pertanian gambir. Gambir merupakan sentral produksi masyarakat setempat untuk memenuhi kebutuhan keluarga. Sehubungan dengan itu, proses dalam pengelohan hasil pertanian pada masyarakat nagari GMUS tidak terlepas dari pengaruh dari toke. Toke adalah seseorang yang dianggap berjasa karena sudah banyak membantu para petani. Bantuan toke kepada petani ini cenderung pada aspek pemberian modal, pemasaran hasil produksi dan peminjaman lainnya seperti untuk keperluan anak sekolah atau ketika ada dari keluarga petani yang sakit.

Kendala yang sering dihadapi masyarakat adalah akses jalan yang kurang baik ditambah dengan jaringan telekomunikasi yang tidak baik, sehingga banyak dari petani pasrah dengan harga yang ditetapkan oleh toke. Petani juga mengeluh bahwa upaya pemerintah dalam mensejahterakan para petani khusunya di Kenagarian Gantiang Mudiak Utara Surantih tidak ada, khusunya akses jalan. Tidak adanya bantuan dari pemerintah, masyarakat berinisiatif untuk menerapkan sistem goro bersama yang dipandu oleh wali Nagari setempat untuk memperbaiki jalan yang rusak dan berlobang. Selain kendala tersebut, Pada masyarakat GMUS, tempat pengolahan hasil pertanian gambir cenderung jauh dari rumahnya dan membutuhkan waktu tempuh perjalanan dua jam berjalan kaki sebab di daerah perbukitan, sehingga membutuhkan biaya untuk pergi kesana, bahkan mereka membutuhkan waktu berhari-hari untuk mengolah hasil produksi. Biaya dalam hal ini sering dikenal oleh masyarakat setempat dengan istilah "baka". Biaya (baka) ini meliputi beras, minyak goreng, ikan teri, minyak tanah, garam, dan alat-alat dapur lainnya yang dibutuhkan oleh petani saat pergi mengolah hasil pertanian gambir. Keterbatasan ekonomi dan kurangnya peralatan kerja, petani cenderung memilih alternatif yang mudah dan rasional menurut mereka untuk meminjam modal yaitu kepada toke. Toke adalah orang yang memberikan modal dan menerima hasil produksi serta memasarkannya ke kota besar. Keberadaan toke merupakan angin segar bagi petani, karena dengan kehadirannya para petani dapat mengolah hasil pertaniannya dengan mudah.

Penelitian ini menjelaskan serta memberikan gambaran mengenai keseharian kehidupan petani gambir dalam memenuhi kebutuhan hidupnya, bertransaksi dengan toke dalam meminjam modal usaha, serta kehidupan sosial yang berkaitan dengan nilai-nilai luhur yang mereka anggap sebagai pondasi dalam menempuh kehidupan sosial yang lebih baik. Adapun nilai-nilai yang mereka anggap berharga dan mesti di pertahankan untuk menjalin kehidupan yang lebih harmonis dengan peneliti amati sepanjang melakukan penelitian adalah: (1) nilai-nilai tolong-menolong, dan (2) nilai-nilai gotong royong. Berikut penjabaran nilai-nilai sosial yang menjadi pedoman petani gambir dalam bertransaksi dengan toke;

\section{Nilai-nilai Tolong Menolong}

Tolong menolong dalam lingkungan kehidupan bermasyarakat adalah suatu keharusan yang harus diterapkan, sebab dengan adanya nila-nilai tolong menolong menjadikan manusia bisa hidup berdampingan. Prinsip dalam kehidupan masyarakat memberikan penjelasan bahwa tolong menolong dengan sesama akan memperkuat hubungan persaudaraan. Sehubungan dengan itu, nilai-nilai sosial adalah sesuatu yang masyarakat anggap sebagal hal yang baik dan buruk (M Miladiyah, 2004). Berikut bagian dari nilai-nilai tolong menolong yang bisa di amati pada masyarakat di Kenagarian Gantiang Mudiak Utara Surantih yaitu; 


\section{Tolong Menolong dalam Lingkungan Keluarga}

Menurut Mattessich dan Hill keluarga merupakan suatu kelompok yang berhubungan kekerabatan, tempat tinggal, atau hubungan emosional yang sangat dekat yang memperlihatkan empat hal (yaitu interdepensi intim, memelihara batas-batas yang terseleksi, mampu untuk beradaptasi dengan perubahan dan memelihara identitas sepanjang waktu, dan melakukan tugastugas keluarga). Keluarga adalah hubungan yang terjalin berdasarkan tempat tinggal, hubungan emosional dan kedekatan dalam hubungan kekerabatan (Lestari, 2012). Petani gambir di Kenagarian Gantiang Mudiak Utara Surantih lebih memilih untuk menjual hasil produksinya kepada kerabat yang dekat denganya. Kondisi ini juga dilandasi atas dasar saling membantu sesama mereka, ditambah lagi dengan ikatan yang sudah dibangun sejak mengolah hasil produksi oleh petani gambir yaitu peminjaman modal. Petani dalam meminjam modal usaha dan menjual hasil produksi lebih mengutamkan kerabat yang dekat dengan mereka ketimbang orang lain.

Tolong menolong dalam lingkungan petani gambir dengan toke di Kenagarian Gantiang Mudiak Utara Surantih merupakan tolong menolong yang bersifat sukarela, dan kerabat yang memintak bantuan tidak merasa terbebani oleh bantuan yang diterima tersebut. sehubungan dengan itu, bantuan yang diterima oleh petani dari kerabatnya yang menjadi toke tidak merasa lebih rendah, sebab bantuan tersebut merupakan pemberian dari kerabatnya sendiri (Ikhwan \& Khaidir, 2003).

\section{Tolong Menolong dalam Persahabatan}

Hubungan dalam konteks persahabatan terjalin secara alamiah ataupun bisa terjadi pada suatu tempat seperti di Sekolah, tempat kerja, satu lingkungan pedesaaan, dan lain-lainya. Dalam hubungan yang terjalin tersebut seseorang saling mengenal sehingga terjadi hubungan persahabatan yang kaut dan erat, apalagi ditambah dengan hubungan persahabatan satu pedesaan yang sering berjumpa dan bergaul dalam lingkungan yang sama. Sehubungan dengan itu, hubungan persahabatan juga cenderung memberikan dampak positif terhadap kehidupan seseorang terutama dalam lingkungan kehidupan petani gambir di Kenagarian Gantiang Mudiak Utara Surantih. Hubungan persahabatan yang terjadi antara petani gambir dengan toke cenderung menimbulkan kemudahan dalam hal peminjamanmodal. Selain itu, hubungan dalam persahabatan cenderung menimbulkan kesenangan, kepercayaan, saling membantu, saling pengertian, dan saling menghargai (Fauziah, 2014). Nilai-nilai kekeluargaan dan nilai-nilai persahabatan di atas adalah bagian dari nilai-nilai kemanusiasan yang mesti diterapkan dalam lingkungan masyarakat. Sehubungan dengan itu, nilai-nilai kekeluargaan dan persahabatan tersebut juga mesti dilandasi dengan nilai-nilai tenggang rasa, kepercayaan dan tanggung jawab. Nilai-nilai tersebut juga diamalkan oleh petani saat menjalin hubungan dengan toke, apalagi saat meminjam modal dan mengembalikan uang yang dipinjam kepada toke. berikut penjabaran nilainilai tersebut;

\section{a) Tenggang Rasa}

Tenggang rasa dalam masyarakat tradisional merupakan simbol dari kehidupan yang harmonis dalam mengerjakan tindakan keseharian, sehingga penerapannya bisa diterapkan dalam lingkungan masyarakat, lingkungan keluarga, kelompok sosial dan lain sebagainya. Sehubungan dengan itu, jika merujuk pada pengertian dalam konteks pancasila tenggang rasa merupakan nilainilai luhur yang mengutamakan sikap menghargai perasaan orang lain (Lestari, 2011). Nilai-nilai tenggang rasa juga terwujud dalam interaksi antara petani dengan toke di Kenagarian Gantiang Mudiak Utara Surantih dalam menjalin kerjasama baik dalam bidang ekonomi dan sosial. Petani menjual hasil pertanian kepada toke dimana mereka meminjam modal dan toke bersedia meminjam modal kepada petani yang membutuhkan tanpa ada pemungutan bunga dari uang yang mereka pinjam. Hal ini merupakan suatu interaksi yang harmonis yang terjalin antara pemilik modal dengan orang yang tidak memiliki modal yang diikat dengan nilai tenggang rasa.

b) Kepercayaan

Nilai-nilai kepercayaan tumbuh dan berkembang pertama kali di dalam diri seseorang melalui lingkungan keluarga. Keluarga adalah unit terkecil dalam lingkungan masyarakat yang 
mengajarkan tahap-tahap awal dalam perkembangan kepribadian seorang anak (Fahrudin, 2014). Oleh sebab itu peran keluarga dalam memberikan pengajaran tentang pentingnnya menumbuhkan nilai-nilai kepercayaan dalam lingkugan masyarakat. Nilai-nilai kepercayaan jika diterapkan dalam lingkungan masyarakat akan memberikan efek yang positif seperti memudahkan dalam bergaul dan berinteraksi dengan sesama.

Kepercayaan pada lingkungan masyarakat merupakan suatu hal yang penting dan fundamental. Penerapan nilai-nilai kepercayaan akan melahirkan suatu sikap lebih mengutamakan keyakinan akan suatu hal dari pada resiko yang akan ditimbulkan. Kepercayaan toke sebagai pemilik modal kepada petani gambir yang meminjamkan uangnya untuk keperluan produksi merupakan suatu hal yang harus dicontoh dan diterapkan dilingkungan sosial. Toke dalam hal memberikan pinjaman kepada petani gambir di Kenagarian Gantiang Mudiak Utara Surantih untuk keperluan produksi tanpa berfikir apakah uang yang dipinjamkan akan kembali atau tidak, ataupun plus dengan bunga yang akan diterimanya. Kemurahan hati dan sifat kepercayaan akan sesama manusia membuat toke menjadi manusia yang anggap sebagai penolong dan katub penyelamat bagi petani gambir di daerah setempat, ditambah dengan pinjaman tersebut tidak mempunyai bunga seperti pinjaman di Bank atau Koperasi desa lainnya. Hal ini menjadi daya tarik tersendiri bagi petani menjalin hubungan dengan toke.

c) Tanggung Jawab

Tanggung jawab adalah nilai-nilai yang mengutamakan sikap yang selalu tepat waktu dalam melaksanakan tugas dan tanggung jawab yang diberikan kepadanya (Wahyu Ahmad, 2014). Nilai tanggung jawab merupakan suatu nilai yang penting untuk diterpakan dalam lingkungan masyarakat manapun, baik dilingkungan pemerintahan, komunitas, bahkan lingkungan masyarakat awam. Masyarakat Minangkabau memahami nilai tanggung jawab lewat pepatah adat, "bakato sapatah dipikiri, bajalan salangkah maliek suruit, muluit tadorong ameh timbangannyo, kaki tataruang inai pandahanyo" artinya; "berkata sepatah dipikirkan, berjalan selangkah lihat kebelakang, mulut terdorong dibayar dengan emas, kaki terdorong di beri inia". Hal serupa juga diterapkan dalam dunia Melayu dikenal pepatah, "tangan mencencang, bahu memukul." Pepatah ini bermakna bahwa siapa melakukan suatu perbuatan atau aktivitas, dia yang harus mempertanggungjawabkannya.

Hubungan yang terjalin antara petani gambir dengan toke di Kenagarian gantiang Mudiak Utara Surantih merupakan hubungan yang bersifat bisnis. Pertukaran yang terjadi antara kedua belah pihak adalah pertukaran yang berlandaskan Azas kepercayaan dan tanggung jawab. Petani sebagai peminjam mempunyai kewajiban untuk mengembalikan modal yang dipinjam pada waktu yang telah ditetapkan yaitu pada saat menjual hasil produksi, sementara toke sebagai si pemberi pinjaman mempunyai tanggung jawab untuk menerapkan nilai-nilai kepercayaan kepada petani yang meminjam modal.

\section{Nilai-nilai Gotong Royong}

Gotong royong merupakan sebauh bentuk partisipasi aktif yang dilakukan oleh setiap indvidu dalam lingkungan masyarakat untuk mendapatkan nilai positif dalam melakukan suatu pekerjaan. Bentuk partisipasi tersebut tidak hanya berupa tenaga fisik semata, namun dukungan berupa materi atau keuangan, keterampilan ataupun yang bersifat ida atau gagasan. Gotong royong pada masyarakat tradisional pada umumnya dilakukan untuk melakukan suatu pekerjaan yang bersifat kepentingan kolektif seperti memperbaiki jalan yang rusak, jembatan, selokan, ataupun yang bersifat perayaan seperti tujuh belas agustus, pesta perkawinan sampai pada kematian. Sehubungan dengan itu, gotong royong juga diartikan sebagai bentuk penyelesaian suatu persoalan dengan cara musyawarah dan mufakat (Effend, 2013).

Gotong royong yang cenderung dilakukan oleh masyarakat di Kenagarian Gantiang Mudiak Utara Surantih adalah memperbaiki jalan yang rusak. Memperbaiki jalan yang rusak adalah sebuah kerja bakti yang dilakukan oleh masyarakat setempat. Kerja bakti atau gotong royong ini tidak hanya dilakukan oleh petani saja, namun keterlibatan toke sebagai orang yang dihargai juga turut andil di dalamnya. Oleh sebab itu, gotong royong menjadi alternatif kebersamaan untuk menyatukan antara petani sebagai orang yang tidak mempunyai modal dengan orang yang memiliki moda. Sehubungan dengan itu, gotong royong juga menunjukan 
bahwa kepedulian seseorang terhadap lingkungan sekitarnya. Kepedulian ini tidak hanya dilakukan oleh petani gambir saja, namun juga didukung dan dibantu oleh toke dan berbagai elit tradisional lainnya. Toke dalam hal ini tidak hanya membantu berupa fisik saja, namun juga materi berupa uang untuk membeli air minum, makanan, rokok, semen dan keperluan lainnya selama bekerja.

Dari observasi yang dilakukan peneliti bahwa keterikatan para petani gambir dalam menjalin hubungan dengan toke tidak hanya sebatas peminjaman modal semata, tetapi juga terdapat nilai-nilai sosial budaya yang ada dan dipertahankan. Nilai-nilai sosial budaya ini mencakup nilai-nilai tolong menolong dalam lingkungan keluarga, lingkungan persahabatan yang di dalamnya terdapat nilai tenggang rasa, tanggung jawab serta nilai-nilai kepercayaana. Dilain pihak, juga ada nilai-nilai gotong royong yang menyatukan antara orang-orang dengan kelas sosial yang tinggi seperti toke dan orang-orang yang berada dalam kelas sosial rendah seperti petani gambir. Sifat gotong royong menjadikan masyarakat senantiasa hidup rukun dan damai. Teori pertukaran yang dikembangkan oleh George C. Homans memiliki asumsi sederhana bahwa interaksi sosial mirip dengan transaksi ekonomi, tetapi pertukaran sosial tidak selalu dapat diukur dengan nilai mata uang, sebab dalam berbagai transaksi sosial dipertukarkan juga dengan hal-hal yang nyata dan tidak nyata.

\section{Kesimpulan}

Berdasarkan hasil penelitian dan pembahasan yang dilakukan, dapat disimpulkan bahwa hubungan antara petani gambir dengan toke di Kenagarian Gantiang Mudiak Utara Surantih merupakan hubungan yang tidak hanya berlandaskan pada konteks transaksi ekonomi semata, melainkan ada hal-hal yang menjadi pilar berdirinya suatu hubungan yang baik harmonis yaitu berupa nilai-nilai sosial yang menjadi acuan bagi mereka untuk berinterkasi dengan sesama, seperti: (1) Nilai-nilai tolong menolong dalam keluarga, (2) Nilai-nilai tolong menolong dalam persahabatan, dan (3) nilai-nilai gotong royong dalam lingkungan masyarakat setempat.

\section{Daftar Pustaka}

Aprizal. (2016). Metode Penelitian Kualitatif. Jakarta: Rajawali press.

Basrowi dan suwandi. (2008). Memahami Penelitian Kualitatif. jakarta: Rineka Cipta.

Effend, T. N. (2013). Budaya Gotong-Royong Masyarakat dalam Perubahan Sosial Saat Ini Tadjuddin Noer Effendi. 2(1), 5. Retrieved from ejournal.upi.edu/index.php/sosietas/ article/download/2871/1904\%0A\%0A

Emzir. (2014). Metode Penelitian Kualitatif Analisis Data. Jakarta: Rajawali press.

Fahrudin. (2014). Proses Pendidikan Nilai Moral Di Lingkungan Keluarga Sebagai Upaya Mengatasi Kenakalan Remaja. Jurnal Pendidikan Agama Islam-Ta'lim, 12(1), 41-54. Retrieved from jurnal.upi.edu/file/04_-_Proses_Pendidikan_Nilai_Moral__Fahrudin.pdf\%0A\%0A

Fauziah, N. (2014). Empati, Persahabatan, Dan Kecerdasan Adversitas Pada Mahasiswa Yang Sedang Skripsi. Jurnal Psikologi Undip, 13(1), 86. https://doi.org/10.14710/jpu.13.1.78-92

Ikhwan, \& Khaidir, A. (2003). Interaksi Pendatang Dengan Masyarakat Asli Dalam Aicilfitas Ekonomi Di Kabupaten MentawaI. 17. Retrieved from repository.unp.ac.id/149/1/ ikhwan_318_03.pdf

Kausar dan Komar Zaman. (2010). Analisis Hubungan Patron-Klien (Studi Kasus Hubungan Toke Dan Petani Sawit Pola Swadaya Di Kecamatan Tambusai Utara Kabupaten Rokan Hulu). Indonesian Journal of Agricultural (IJAE), 2, 97-119.

Lestari. (2011). Hubungan antara pengetahuan tentang konsep tenggang rasa dengan sikap sosial siswa di sdn rambutan 03 pagi jakarta timur. 3. Retrieved from https://id-static.zdn.net/files/dfd/015f12198c7a3dea6bddeee49c886b54.pdf\%0A\%0A

Lestari, S. (2012). Psikologi keluarga: Penanaman nilai dan penanganan konflik dalam keluarga. Psikologi, (Zeitlin 1995), 1-16. https://doi.org/10.1249/01.mss. 0000074580.79648.9d

Lies Sulistyowati, Ronnie S Natawidjaja, dan Z. S. (2013). Faktor-Faktor Sosial Ekonomi Yang Mempengaruhi Keputusan Petani Mangga Terlibat Dalam Sistem Informal Dengan Pedagang Pengumpul Lies Sulistyowati, Ronnie S Natawidjaja, dan Zumi Saidah Program Studi Agribisnis, 
Fakultas Pertanian Universitas Padjadjaran. 15(3), 285-293.

M Miladiyah. (2004). Nilai-Nilai Sosial. 28. Retrieved from digilib.uinsby.ac.id/1289/5/Bab 2.pdf $\% 0 \mathrm{~A} \% 0 \mathrm{~A}$

Mariana, R. (2012). Pengaruh Harga, Tenaga Kerja, dan Modal Kerja Terhadap Pendapatan Petani Gambir di Kenagarian Gantiang Mudiak Utara Surantih Kabupaten Pesisir Selatan.

Moehar, daniel. (2004). Pengantar Ekomomi Pertanian. jakarta: Bumi Aksara.

Puwardi Kristi. (2001). Penelitian kualitatif Untuk Prilaku Manusia. jakarta: Fakultas Psikologi Universitas Indonesia.

Soerjono, soekanto. (2010). Sosiologi Suatu Pengantar. Jakarta: Rajawali press.

sugiyono. (2007). Metode Penelitian Kuantitatif, Kualitatif dan R\&D.

Suyanto Bagong dan Sutina. (2015). Metode Penelitian Sosial: Berbagai Alternatif Pendekatan. jakarta: Pranemedia Group.

Usman, Romis and Ma, Farid th musa and Latare, Z. (2015. (2015). Pola Hubungan Sosial Masyarakat Petani Dengan Tengkulak (Studi Kasus Hubungan Patron Client Pada Masyarakat Petani di Desa Tenilo Kecamatan Tilamuta Kabupaten Boalemo). 2015.

Wahyu Ahmad. (2014). Implementasi Nilai-nilai Karakter Dalam Pembelajaran Akidah Akhlak Peserta Peserta Didik Di MTsN Sumberagung Bantul Yogyakarta. Cell, 151(4), 14. https://doi.org/10.1016/j.cell.2009.01.043

Yusuf, Muri. (2016). metode penelitian (kuantitatif, kualitatif, dan penelitian gabungan). jakarta: Pranemedia Group. 